Article

\title{
The Dark Side of Inspirational Pasts: An Investigation of Nostalgia in Right-Wing Populist Communication
}

\author{
Manuel Menke ${ }^{1, *}$ and Tim Wulf ${ }^{2}$ \\ ${ }^{1}$ Department of Communication, University of Copenhagen, 2300 Copenhagen, Denmark; \\ E-Mail: manuel.menke@hum.ku.dk \\ 2 Department of Media and Communication, LMU Munich, 80538 Munich, Germany; E-Mail: tim.wulf@ifkw.Imu.de \\ * Corresponding author
}

Submitted: 30 October 2020 | Accepted: 15 January 2021 | Published: 6 May 2021

\begin{abstract}
In recent years, research found that populism employed a new strategy by using nostalgia, a sentimental longing for the past, as a communication tool to persuade citizens to support their political agendas. In populist campaigns, nostalgia is used to affectively link (alleged) crises with longing for a cherished past. In this article, we applied a mixed-methods approach to understand how populists exploit nostalgia in their communication and how nostalgic rhetoric has the potential to persuade people to support their claims. In Study 1, we conducted a case study based on a qualitative content analysis of Alternative for Germany's (AfD) online election campaign in the 2019 Thuringia election in East Germany. The analysis revealed that the campaign was built around the nostalgic narrative of the 1989 peaceful revolution as a proud historical moment for former German Democratic Republic citizens while at the same time creating a sense of crisis supposedly caused by false post-reunification politics. To further investigate the persuasiveness of nostalgia, Study 2 used a statement from the campaign and found that participants tended to agree more with populist statements if they contained nostalgic rhetoric (compared to non-nostalgic populist and control rhetoric). These findings suggest that right-wing populists can effectively exploit nostalgia and that it may 'sugarcoat' populist messages.
\end{abstract}

\section{Keywords}

Alternative for Germany; collective nostalgia; German Democratic Republic; online election campaign; persuasion; political communication; populism

Issue

This article is part of the issue "The Good, the Bad, and the Ugly: Inspirational Media between Meaning, Narration, and Manipulation" edited by Lena Frischlich (University of Muenster, Germany), Diana Rieger (LMU Munich, Germany) and Lindsay Hahn (University at Buffalo-State University of New York, USA).

(C) 2021 by the authors; licensee Cogitatio (Lisbon, Portugal). This article is licensed under a Creative Commons Attribution 4.0 International License (CC BY).

\section{Introduction}

Nostalgia, a sentimental longing for the past, has become an omnipresent phenomenon in popular culture. For many, it is entertaining and inspiring to nostalgically engage in fond memories evoked by media (Daneels, Bowman, Possler, \& Mekler, 2021; Kay, Mahoney, \& Shaw, 2017). However, nostalgia is not an exclusive asset in the entertainment business but also attracts notice in politics. Since the 1990s, the use of nostalgia as a political tool has become a widespread in Eastern Europe after the transition to democracy and market economy resulted in many unfulfilled promises and a longing for a better future (Velikonja, 2009). Realizing the potential of this frustration, politicians made use of the fact that post-Soviet nostalgia "[f]ueled by dissatisfaction with the present, creates and feeds the image of the perfect past" (Velikonja, 2009, p. 538). This is a rather recent example in a long history of political uses of the past across the political spectrum. Nostalgia has also proven itself to be compatible with the conservative politics of the right, defending traditions and values against change (Bourke, 
2018, p. 453; Tannock, 1995, p. 455). The continuum between constructive and 'dark' uses of nostalgia varies depending on the political stance of those who employ it (Bonnett, 2010). As we will show, those with radical or extreme agendas tend to exploit nostalgia for emotional manipulation to either stabilize or mobilize against the status quo (Karakaya, 2020).

Subsequently, we focus on the 'dark' end of the continuum. In recent years, nostalgia's persuasive potential as an affective communication tool was also discovered by modern right-wing populists across the globe (Betz \& Johnson, 2004). The most prominent examples date back to 2016, culminating in the slogans "Make America great again" (Trump, US presidential campaign) and "Take back control" (Independence Party, UK Brexit campaign; Campanella \& Dassù, 2019). These campaigns are representative of a trend that illustrates the strategic use of nostalgia as a means of persuasion in populist politics (Lammers \& Baldwin, 2020). Hence, nostalgia paved at least some of the way towards the success of contemporary populism in modern democracies.

While there has been some case-based work on the relationship between populism and nostalgia in several countries, such as the US, the UK, and Turkey (Browning, 2019; Karakaya, 2020; Kenny, 2017), research on how nostalgia is used in mediated populist communication and nostalgia's persuasive potential in populist messages is rather scarce. To contribute to these questions, we conducted a qualitative content analysis (Study 1 ) investigating the use of nostalgia in the online campaign of the right-wing populist party Alternative for Germany (AfD) during the Thuringia federal state election in 2019. Building on an example from the online campaign material, we then followed with an experiment (Study 2) examining the persuasive potential of nostalgia in statements about safety in public places. Our findings show how nostalgia is used in the campaign to create a nostalgically informed vision of the future combined with rigid in- and out-group thinking in times of crisis. By creating positive emotions that are evoked when individuals fondly remember the past, nostalgia may work to 'sugarcoat' populist messages that would-otherwisebe rejected more easily.

\section{2. 'Dark' Uses of Nostalgia in Right-Wing Populism}

Nostalgia is neither political nor 'dark' per se: it can be pleasurable, fun, social, and entertaining. There has been extensive research in recent years that underscores the cultural, social, and psychological benefits of nostalgia as a productive engagement with the past (Menke, 2017; Wildschut, Sedikides, Routledge, \& Arndt, 2006; Wulf, Bonus, \& Rieger, 2019). Research in social psychology shows that whenever people feel nostalgic by remembering meaningful events from their life, they usually feel connected to their peers (Wildschut, Sedikides, Routledge, Arndt, \& Cordaro, 2010), develop a sense of meaning in life (Van Tilburg, Igou, \& Sedikides,
2013), and find continuity in their biography (Sedikides et al., 2016).

At the same time, it is positive elements such as these that make nostalgia's exploitation for political purposes so dangerous. Svetlana Boym (2001) exposed this ambivalence of nostalgia in her well-established differentiation between "restorative nostalgia" that aims at reinstating a lost past as an absolute, dead serious truth and "reflective nostalgia" that allows one to long for the past as an inspirational resource to engage with the progress of time and the changes that come with it. Regarding the former, Boym observed that "[restorative] nostalgia characterizes national and nationalist revivals all over the world" (2001, p. 41) and warned that "[t]he mix of nostalgia and politics can be explosive" (2007, p. 10). To further investigate their relationship, it is important to outline which features of nostalgia are compatible with core elements of right-wing populism.

\subsection{Nostalgia as an Affective Tool in Right-Wing Populist Communication}

The extensive literature on populism shows that there is a long-lasting debate about what populism is and what its features are. We will not go further into the many conceptual differences between populism as a zeitgeist, thin-ideology, political style, pathology, form of discourse, or strategy (Moffitt \& Tormey, 2014; Mudde, 2004; Stanley, 2008), nor into the literature of all elements of populism, such as the refusal of established political practices and norms, a tendency to authority, and a fascination with charismatic leaders (Taggart, 2004, pp. 275-276). Instead, we will focus on those elements constituting the affective dimensions of right-wing populism which we consider particularly relevant to understand why nostalgia is such a powerful affective communication tool.

First, right-wing populism promotes a narrative of a world in crisis to create a sense of loss of control. Typical scenarios include economic decline, moral decay, and threatening cultural shifts (Inglehart \& Norris, 2016; Taggart, 2004, p. 275). This materializes in a "loss frame" which suggests a loss of status, purpose, and wealth due to the devastating impact of a crisis to create "ontological insecurity," i.e., a loss of trust in the world and one's place in it (Steele \& Homolar, 2019, p. 219). When right-wing populists actively promote such a perception, this fosters feelings of anxiety, fear, and discomfort with the present.

In nostalgia research, this emotional state, rooted in a (perceived) crisis and experiences of disruption and loss, has long been identified as an important trigger of nostalgia (Davis, 1977; Pickering \& Keightley, 2006). Nostalgia can be a way of coping with change and thereby can be addressed in the right-wing populist vision that capitalizes on the previously fostered 'ontological insecurity' to restore a sense of identity, self-continuity, and security (Smeekes, Wildschut, \& 
Sedikides, in press). The solution presented by populists pictures a nostalgically informed vision for the future that overcomes the criticized status quo and promises to reinstate past certainties (Wohl, Stefaniak, \& Smeekes, 2020, p. 484). A series of three experimental studies by Lammers and Baldwin (2020) indicates that, indeed, nostalgia supports right-wing populist rhetoric if the depicted past suggests that things used to be easier. The authors conclude that "[i]t is easy to see why right-wing populism may be linked to collective nostalgia. Many of the slogans used by right-wing populist parties appeal to this collective emotion by calling for a return to the past" (Lammers \& Baldwin, 2020, p. 944). The 'darkness' of this lies in the exploiting of the powerful affective link between the asserted state of crisis, the induced ontological insecurity, and the promise to retrieve a romanticized past which, however, never existed in the first place (Kenny, 2017).

Recent case studies show how nostalgia works in right-wing populist campaigns: For the Brexit campaign, Browning (2019, p. 235) describes that populists targeted the so-called 'left behind' who already felt "economically, socially and ontologically insecure" and attributed their situation to "globalization, economic transformation, multiculturalism and immigration" as well as unbearable EU regulation. The Brexit campaign then promised a "returning to a national homeland associated with community cohesion, job security and belonging" and a renewed recognition of the British nation (Browning, 2019, p. 235). Kenny (2017, p. 527) observed the same affective tropes of crisis and former glory within Trump's campaign, indicating that the outlined scheme is based on a shared discursive pattern. Drawing from her research on Ottoman nostalgia in Turkish populism, Karakaya (2020, p. 153) also points out that populist campaigns share rhetoric that connects sufficiently to restorative nostalgia by dividing the world into a binary of a cherished past and a despised present. In all three examples, populists intentionally communicated this superior past rather vaguely to allow individuals to fill the gaps with their own imagined version of the collective past. In these campaigns, right-wing populists capitalized on the "mobilizing emotional force" of nostalgia that evokes a bonding passion and encourages support of the common agenda (Karakaya, 2020, p. 152). The research shows many commonalities, yet each populist campaign is adjusted to the "local nostalgias" anchored in different national and historical contexts (Karakaya, 2020, p. 153).

\subsection{Drawing on Nostalgia for In- and Out-Group Construction}

Nostalgia can turn even 'darker' when the vision for society only caters to the needs of a specific in-group and disregards or threatens those declared members of outgroups. That the construction of the in-group entails a strong affective dimension has been stressed by Taggart in the notion of the 'heartland.' Even though Taggart did not explicitly label the 'heartland' nostalgic, core features are present in his description:

The heartland is a construction of an ideal world but unlike utopian conceptions, it is constructed retrospectively from the past-it is, in essence, a pastderived vision projected onto the present as that which has been lost.... It is a diffuse vision, blurred around the edges but no less powerful for that. It is no doubt romanticised and a profoundly ahistorical conception but, again, no less powerful for that. (Taggart, 2004, p. 274)

In right-wing populism, the 'heartland' only comprises citizens who are considered members of the country's native ethnic group. The 'us vs. them' mentality is baked into the nostalgic vision of a nation for the natives as it was before the out-groups supposedly corrupted it (Smeekes, 2015). The in-group is constructed around the notion of the 'common man' who is portrayed as the unjust victim of change caused by non-native outgroups, such as foreigners and refugees, and powerful elites, such as politicians and progressive intellectuals (Mudde, 2004, p. 543). It is only the idealized past of this targeted in-group that right-wing populists promise to restore, explicitly excluding minorities and elites who are considered dissidents (Hameleers, 2018). Hence, the danger of exploiting nostalgia for the 'heartland' lies in relating the nostalgic sentiments of the in-group to the suggested question of why things have changed for the worse for them and who is responsible for it (Smeekes, 2015).

In their communication, populists orchestrate what Smeekes et al. (in press) call an emotion-based 'masterframe' of national nostalgia: Praising the national past creates a sanctuary of positive emotions among receptive members of this in-group. Coincidentally, they arouse the perception that this sanctuary has been taken which results in longing and anger about the loss that is eventually channelled towards xenophobia and anti-elitism. Various experiments in social psychology support the claim that nostalgia for the own in-group's past leads to in-group identification and out-group prejudice (Smeekes, 2015; Wohl et al., 2020). In a study with participants from 27 countries, Smeekes et al. (2018) also demonstrated that when the in-group was under threat, collective nostalgia increased which in turn led to opposition towards immigrant out-groups. Finally, being receptive of stories relating to the nation's past as a glorious time is linked to xenophobic and nationalistic attitudes (Smeekes, 2015; Smeekes et al., in press). In line with these results, it is plausible that populist attitudes also make individuals more prone to nostalgic populist statements. From here, we expect that nostalgic rhetoric increases people's agreement with populist statements (H1) and that such agreement should depend on individual populist attitudes ( $\mathrm{H} 2)$. 
Following the literature review, we will now introduce the German case we investigated in two empirical studies on the uses of nostalgia in populism, starting by briefly outlining the political and historical context.

\section{The Thuringia Federal State Election of 2019 and Alternative for Germany}

The AfD was founded in 2013 as a right-liberal EU-sceptic populist party which has since then increasingly moved to the right. In the 2019 election in the East German federal state Thuringia, AfD and their head runner Björn Höcke successfully mobilized $23.4 \%$ of the votes. The party secured second place and was able to double the result from 2014 (10.6\%).

The success of AfD Thuringia is attributed to numerous historical roots: After reunification, the promised prosperity did not materialize. Furthermore, historians showed that West Germany cultivated a pedagogical approach to history that condemned the German Democratic Republic (GDR) as a regime without acknowledging that many former GDR citizens felt that their biographies were delegitimized and their voices were excluded from the discourse (Saunders \& Pinfold, 2013). Even after 30 years, many old and young East Germans report "[feelings of] social disintegration and a lack of recognition" by West Germans (Weisskircher, 2020, p. 620). This underpins a foundation of mistrust in the political system and its capability to represent East Germans' needs. Finally, there is a comparably high level of anti-immigrant attitudes that researchers trace back to a lack of intercultural experiences in the GDR and today's East Germany, which has contributed to the success of right-wing politics since the 1990s (Weisskircher, 2020, p. 619).

Against this backdrop, we chose to analyse the online campaign of AfD, which carried the main slogan “Wende_2.0" (Turnaround_2.0, authors' translation). It refers to the 1989 turning point of the peaceful revolution and taps into the subsequent inner-German struggle of reunification. With this reference, AfD set up the campaign around the trope of the peaceful revolution of former GDR citizens being their glorious moment in history that led to the overthrow of the socialist regime. To gain insight into the populist uses of nostalgia in this campaign, we combined a qualitative content analysis to explore the actual nostalgic populist communication (Study 1) with a follow-up experiment, using a message from the campaign, to test the assumptions regarding people's agreement with nostalgic rhetoric (Study 2).

For the case in Study 1, we explore four research questions:

RQ1: How was the narrative of the 'Turnaround_2.0' established in the campaign material?

RQ2: How was nostalgia for the 'heartland' used to foster a xenophobic in- and out-group mentality?
RQ3: How did AfD Thuringia make use of the nostalgic sentiments for the peaceful turnaround of 1989 and the 'heartland' to mobilize voters with their online campaign?

RQ4: How was nostalgia tied to right-wing populist elements in AfD's online communication?

For the experiment in Study 2, we pose the two hypotheses as derived in the theory above:

H1: Participants more strongly agree with nostalgic right-wing populist rhetoric compared to nonnostalgic right-wing populist rhetoric.

H2: Populist attitudes moderate the impact of nostalgic rhetoric on agreement with those messages.

The studies were developed and executed together with students in a seminar, while the final analyses of the data were performed by the authors. Data and supplementary material are available online (https://doi.org/ 10.17605/OSF.IO/ZNPGT).

\section{Study 1: Case Study of the AfD Online Election Campaign}

Study 1 explores the 'dark' uses of nostalgia in AfD's communication aiming at answering the first four RQs posed above. All quotes are English translations by the authors.

\subsection{Method}

\subsubsection{Sample and Selection Criteria}

In the first phase, we chose to gather official AfD campaign material from AfD Thuringia's website and Facebook accounts from the four weeks before the election on the 27th of October 2019. We expected to find the most unfiltered communication online because it is there that right-wing populists are able to directly address their followers and circumvent traditional media (Krämer, 2017, p. 11). We only selected material that either directly promoted the 'Turnaround 2.0' campaign or included content related to the 'heartland' covering topics such as family values, education, the homeland, German identity, and immigration, because the literature indicated a clustering of nostalgic statements with these topics. In the second phase, we only selected paragraphs or sections for the analysis if they included (1) (nostalgic) references to the past and at least one populist element, such as (2) loss/crisis in the present and/or (3) the 'heartland' and/or (4) anti-elitism and/or (5) out-groups. The final sample comprised posts from AfD Thuringia's Facebook account ( $n=24 ; 1,054$ words), and the Facebook account of Björn Höcke $(n=13 ; 2,012$ words); campaign videos from AfD Thuringia's website 
( $\mathrm{n}=2 ; 3: 00 \mathrm{~min}$ ); paragraphs on migration, family values, education, culture, and security from the election manifesto ( $n=1 ; 3,236$ words); online pamphlets on the homeland, family values, immigration, and East-German identity ( $n=5 ; 6,761$ words); and election campaign posters with one-line slogans $(n=10)$.

\subsection{Coding}

The coding process followed three consecutive stages. First, the authors created a basic coding scheme that included the main categories deductively derived from the theory on nostalgia and populism. This comprised for nostalgia:

(1) Restorative nostalgia: Statements that present the past as an ideal time that should be restored (Boym, 2001). This can refer to either a national past and/or a vague bygone 'heartland' that is often contrasted to an inferior present (Lammers \& Baldwin, 2020; Smeekes et al., in press; Taggart, 2004).

(2) Nostalgic sentiment: Statements that address an emotional state related to the past or the contrast between the present and the past. The 'bittersweetness' of nostalgia manifests in the expression or reflection of positive (sweet: comfort, joy, solidarity) and negative (bitter: anger, sadness, disappointment) emotions (Wildschut et al., 2006).

(3) References to the past: Statements that refer to the historical era and events related to the GDR and the 1989 Turnaround as well as East German's personal and collective memories of their everyday life in the GDR (Saunders \& Pinfold, 2013).

For populism, these were:

(1) In-group construction: Statements that emphasize the origin of East Germans based on nativism/ nationalism and/or shared values and (nostalgic) emotions (Smeekes, 2015).

(2) 'Heartland': Statements that refer to the past as a time with specific ideals that constitute the collective identity of East Germans based on family values, shared convictions, in-group solidarity, and native exclusivity (Taggart, 2004).

(3) Anti-elitism: Statements in which West German politicians are made responsible for the supposed crisis within East Germany and Thuringia. Criticism claiming the failure of democracy due to the corruption of democratic institutions by elites (Mudde, 2004).

(4) Out-groups: Statements that are othering nonnative or non-East German people, such as immigrants, refugees (especially Muslims), or West Germans by condemning their values, motives, and behaviour (Smeekes, 2015; Smeekes et al., in press).
(5) Change/crisis: Statements that discuss social, cultural, and political change in a sensational tone as harmful for the native in-group. Usually, crises are attributed to elites and out-groups (Inglehart \& Norris, 2016; Steele \& Homolar, 2019).

(6) Loss frame: Statements that frame social, cultural, and political change in terms of what the in-group has lost or what has been taken away from its members by elites or the out-group (Steele \& Homolar, 2019).

In the second stage, the coding scheme was used by the students ( $n=14$; in 4 groups) to code all material based on the principles of directed content analysis to discover patterns and themes (Hsieh \& Shannon, 2005; Mayring, 2014) using the qualitative data analysis software f4analyse (Dresing \& Pehl, 2020). Each group used the same initial coding scheme and inductively added codes to the main categories that covered the different sub-dimensions found within the empirical material, such as a differentiation of in-group and out-groups regarding the sub-dimensions of culture, nationality, ethnicity, religion, and political tradition or the 'heartland' as a shared culture, a geographical location, or the nature of the homeland. In the third stage, the four coding schemes of the groups were fused into one final comprehensive version by the authors. This version was then employed by one of the authors to code the material. This coding was finally reviewed by both authors and compared to the students' coding for reference. Only minor adjustments followed this step. We subsequently present our results based on this coding and the patterns and themes that were identified in AfD's communication across the material of the sample.

\subsection{The 'Dark' in Technicolor Communication}

In this section, we will demonstrate how AfD established the narrative of the 'Turnaround_2.0' in the campaign material (RQ1) that became the major reoccurring theme. Besides the digital aesthetic of the '2.0,' this is a reference to the German peaceful revolution of 1989 overthrowing the GDR regime. Thus, the slogan addresses an achievement of courageous former GDR-citizens and nostalgically celebrates their role in this historical event. We will subsequently show how nostalgia for this glorious moment was used by AfD to mobilize East Germans for yet another turnaround at the ballot boxes.

As Figure 1 shows, the outlined common nostalgic theme is present in technicolour campaign videos available on AfD Thuringia's website and on Facebook. In this video (AfD Thuringia, 2019a), the "1989" reference with protesting people in the background is followed by the lettering "peaceful revolution." It is then pointed out that "30 years after" the former GDR citizens fought in the revolution they have been "disappointed." Title stories of West German newspapers about East Germany are 

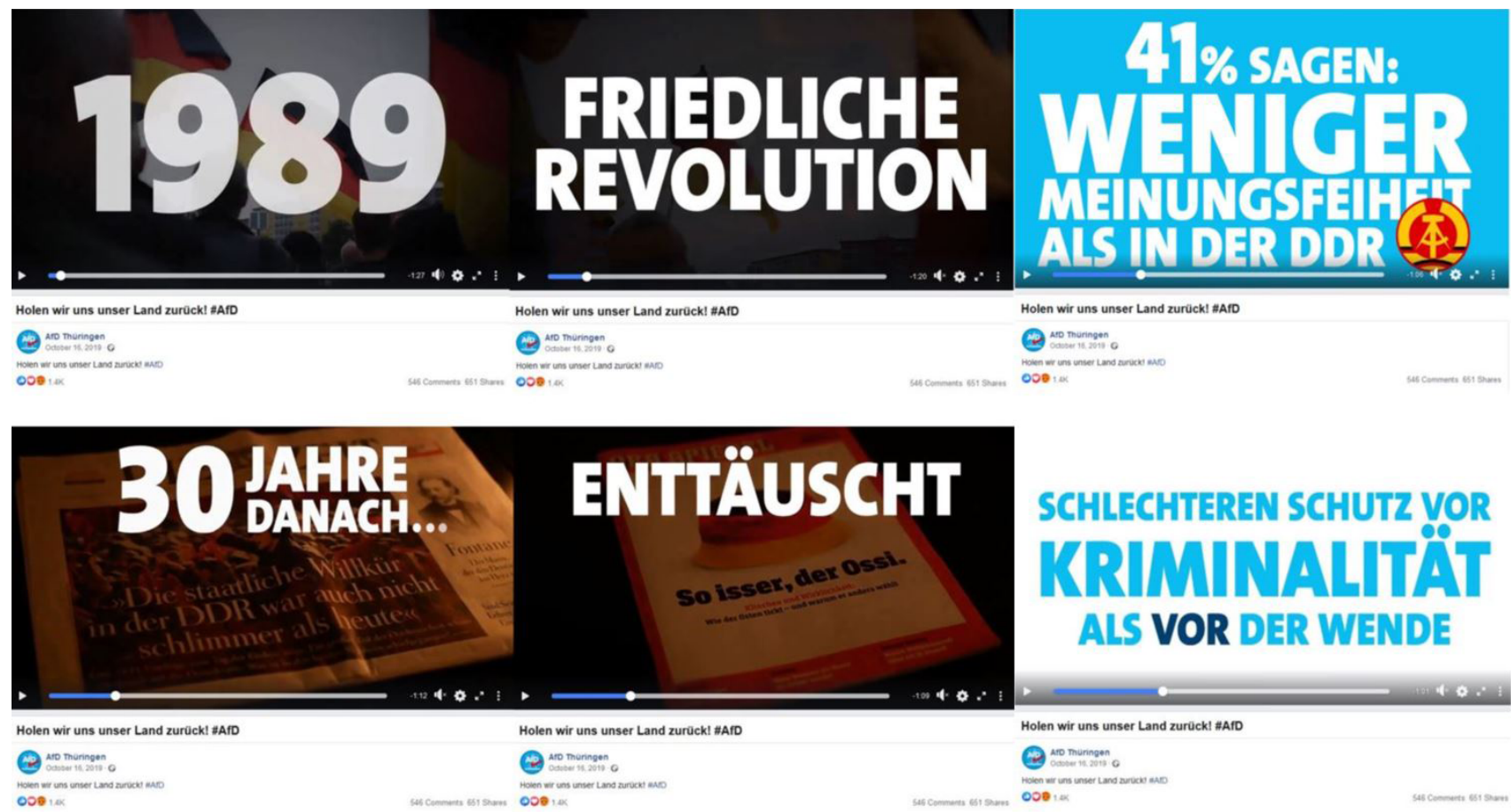

Figure 1. Six screenshots taken by the authors from the AfD Facebook video "Let us take our country back! \#AfD." Source: AfD Thuringia (2019a).

used as a symbol for the arrogance of West Germans and 'their' media. The blue screenshots on the right show two statements from the video arguing that the present is even worse than the GDR regime: " $41 \%$ say: Less freedom of speech than in the GDR" and "Worse protection from crime than before the turnaround."

The combination of nostalgia and populist elements also becomes explicit in AfD's election manifesto titled "My home, my Thuringia," which was available on the website (AfD Thuringia, 2019b). It includes statements such as: "It is with great concern that we observe that in recent years the liberal democracy for which the people fought during the peaceful revolution has increasingly been transformed into a spectator democracy with features of an ideological regime" (AfD Thuringia, 2019b, p. 7). This sentence prototypically represents most elements of the populist scheme: crisis, anti-elitism, and nostalgia. Other equal examples in the online campaign are a comic and a radio commercial visualized in a video. As Figure 2 demonstrates, the cartoonish style resembles harmless children's media with an entertaining appeal. However, beyond the playful aesthetic, there are layers of nostalgic narratives combined with 'dark' elements, such as the scenario of the crisis and the blaming of West German elites, the government, and left progressives. In the cartoon, Björn Höcke (top left) praises the former GDR citizens for their bravery in the peaceful revolution while the situation in Germany is compared to the oppression during the GDR.

In the party's campaign newspaper and on Facebook, we also found similar techniques to create a sense of crisis and evoke nostalgic sentiments. The hashtag
\#VollendeDieWende (\#AccomplishTheTurnaround) was used for most Facebook posts and an encouraging tone

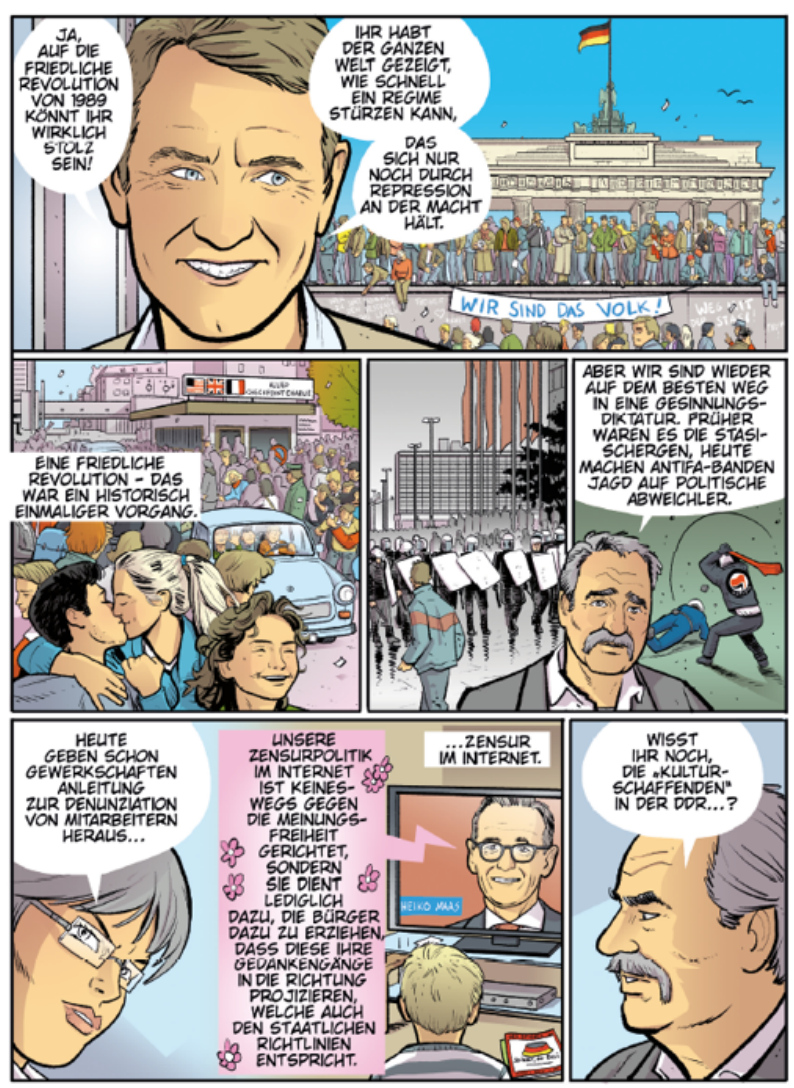

Figure 2. Screenshot of AfD comic "Fed up with bloc parties." Source: AfD Thuringia (2019c). 
was often employed to mobilize voters: "30 years after the peaceful revolution, it is time for a revolution at the ballot box" (AfD Thuringia, 2019d).

Finally, on the campaign posters, there were many motivational slogans related to the same nostalgic trope combined with attacks towards West German elites: "Turnaround_2.0: Write history! 1989-2019 Complete the turnaround," "Turnaround_2.0: They had 30 years!," and "We wanted freedom and got an eco-dictatorship!" (AfD Thuringia, 2019e).

\subsection{When the In-Group Nostalgia Turns into Out-Group Xenophobia}

Additional to the 'Turnaround_2.0' narrative, we will subsequently demonstrate how the campaign also fostered an in- and out-group mentality (RQ2). Xenophobia is present in communication across different media employed in the campaign. In the video screenshots provided in Figure 3, there is an explicit focus on the 'heartland' that evokes nostalgia for the nuclear family living in the countryside. The countryside is portrayed as the place to return to nature, get a good education, and live a secure life based on traditional values. Living in the multicultural city is contrasted by a Muslim family comprised of a man with two wives in burkas, accompanied by the word "Sharia." The video concludes with the claim that Thuringia has changed and needs to be restored: "Together we accomplish the turnaround" (AfD Thuringia, 2019f). The German flag, omnipresent in all campaign material, is additionally used as a demarcation between the natives and those regarded as cultural and ethnic out-groups.

In the party's election manifesto and thematic online pamphlets, nostalgic narratives were embedded in their argumentation for future 'heartland' policies. The party claimed their central concern is "to preserve, protect, educate, and promote the rich culture of our homeland" because "[f]or Thuringian AfD, cultural life is both the basis and expression of our identity" (AfD Thuringia, 2019 b, p. 80). This particularly concerns the claim that the nuclear family is under threat because "[v]arious forces in politics, the economy, and society are working against parenthood and thus against the family" (AfD Thuringia, 2019g, p. 15). This is mixed with xenophobic positions when the party argues that immigrants exploit the welfare system, are criminals, and are used by the government to tackle the superannuation of the German population. AfD claims that this results in "considerable disadvantages for the ancestral population" (AfD Thuringia, 2019b, p. 50) while the party "pursues a family policy that aims to enable the German people to reproduce themselves in the long term from within themselves" (AfD Thuringia, 2019g, p. 33).

Höcke painted a particularly dark picture of Germany when he wrote on Facebook:

Mass migration from the Far East and Africa, Islamic extremism, the decay of domestic security, rise in crime, rule by Arab clans, general brutalization and neglect; the Euro crisis, expropriation of savers by a zero-interest policy of the ECB, the destruction

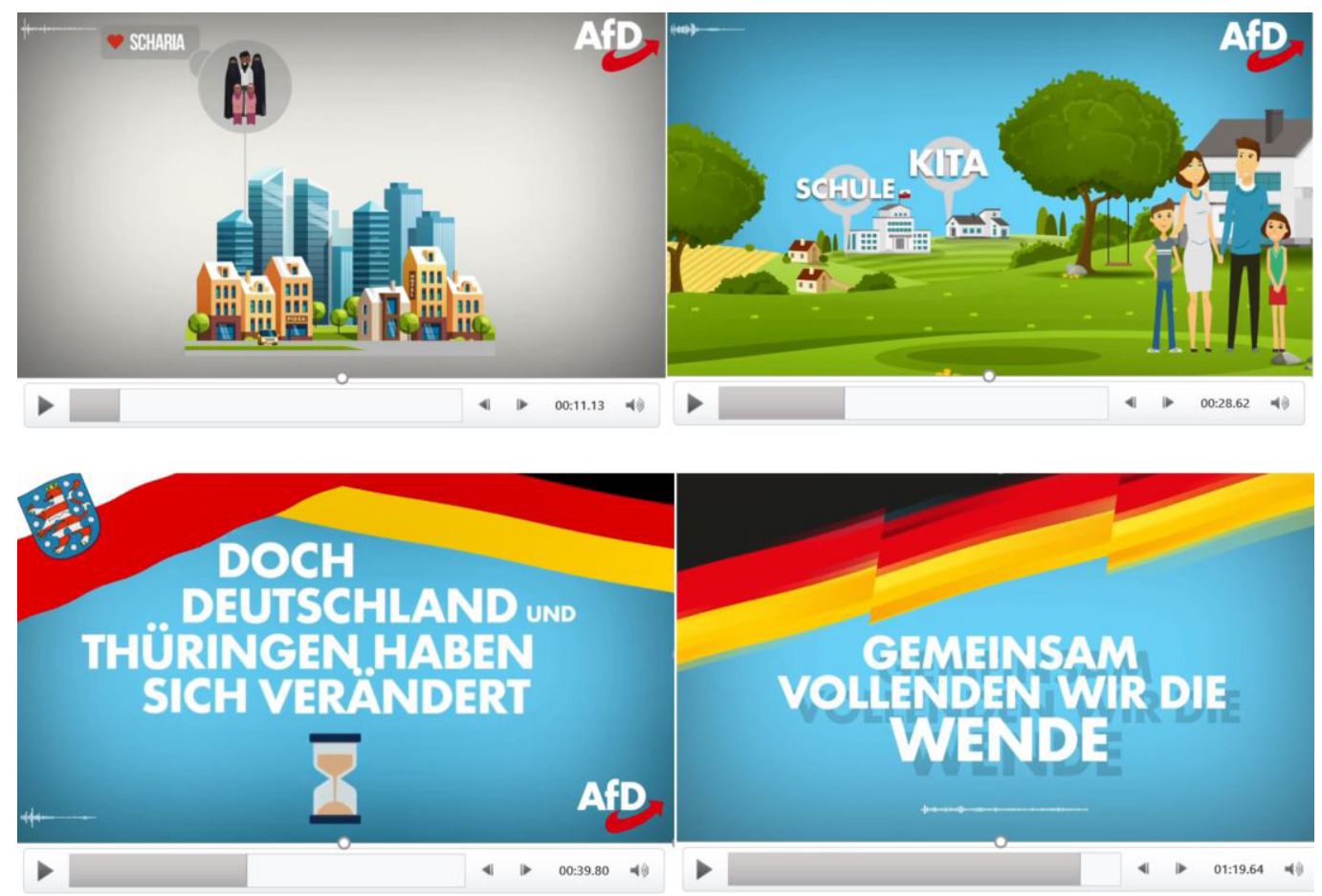

Figure 3. Four screenshots taken by the authors from AfD video "Radio commercial of AfD for the Thuringia federal state election on 27.10." Source: AfD Thuringia (2019f). 
of the German automobile industry, destruction of jobs; the disfigurement of the landscape by wind turbines, increases in electricity prices, poverty in old age-these are the consequences of a misguided policy that is no longer guided by benevolence. (Höcke, 2019)

This quote demonstrates how the claimed crises are tied to specific out-groups and elites while at the same time suggesting concern for the needs of the 'common man' and evoking nostalgia for the loss of the traditional norm of benevolence.

\subsection{Nostalgia as an Affective Tool for Mobilization}

Based on the examples that illustrated how nostalgia manifested in the campaign (RQ1 and RQ2), we will now elaborate further on how AfD Thuringia made use of the nostalgic sentiment for the peaceful turnaround of 1989 and the 'heartland' in their online campaign (RQ3). At first appearance, the previous analysis showed that AfD employed the typical nostalgic populist scheme that has already been described in the literature by Smeekes et al. (in press), Karakaya (2020), and Kenny (2017), yet there were also insightful deviations.

The claimed crises of democracy and German national identity fit the known conventional populist strategy. Here, however, nostalgia was used for two very different purposes. Nostalgia for the 1989 turnaround was particularly exploited to mobilize East Germans for a second peaceful revolution aka the 'Turnaround_2.0' at the ballot box. By comparing the oppressive GDR regime to the present political circumstances, the urgent need for a 'Turnaround_2.0' was suggested. This nostalgia was not about a superior historical era but about the proud collective memory of one outstanding moment in time. The 'Turnaround_2.0' was portrayed as the only solution to once more change the course of history and return to a state in which there is potential for a better future.

The second type of nostalgia in the material concerned the German 'heartland.' This nostalgia was used to design a long-term right-wing political vision based on an agenda catering to the native East German in-group longing for ontological security. AfD constructed the idea of a 'heartland' around traditional values and the native descent of the in-group rather than around a specific historical past. This allowed them to disregard the GDR and to instead create a vision based on German nationalism and identity that potentially captures a broader audience. The examples from the material show that immigrants and refugees, i.e., particularly Muslims, as well as left progressives were portrayed as those threatening the 'heartland.'

The examples presented in our analysis also show how nostalgia was tied to right-wing populist elements in AfD's communication (RQ4): Most importantly, it was the fear of crisis and loss, anti-elitism, and xenophobia that were present in combination with nostalgia. The nos- talgia for the peaceful revolution mostly made use of the crisis trope and the anti-elitism regarding the state of democracy. The nostalgia for the 'heartland' focused more on German identity based on values, ethnicity, and xenophobia. In sum, these populist and nostalgic elements were strategically combined for two different purposes: the first to affectively mobilize against the political system in the election and the second to mobilize for a right-wing political agenda based on nationalism and xenophobia.

\section{Study 2: Experiment on Nostalgic Populist Statement's Persuasiveness}

Based on the findings of Study 1, we decided to conduct an experiment with material from the AfD campaign to investigate how nostalgia makes populist messages more persuasive.

\subsection{Method}

\subsubsection{Participants}

We recruited 235 participants via social media postings and student mailing lists at a large university in Germany. We excluded 62 participants who did not finish the questionnaire leaving a final sample of $N=173$. The dropout rate did not differ between experimental groups. The average age of our sample was $M=28.39$ $(S D=13.20)$ with $64.5 \%$ identifying as female (1 participant as non-binary). The sample showed an overall high level of education: $46.5 \%$ had a high school diploma, $23.5 \%$ a university degree, $13.5 \%$ had finished training in a skilled trade (abgeschlossene Lehre), only $16.5 \%$ had a lower-school degree (or had not yet finished school). Participants were randomly assigned to conditions. Analyses suggested that randomization was successful as neither age $[F(2,165)=0.43$, n.s.] nor gender distribution $\left[\chi^{2}(2)=0.74\right.$, n.s. $]$ differed between groups.

\subsubsection{Procedure}

After providing informed consent, participants first answered general questions about their political interests. Afterwards, participants answered a questionnaire on their populist attitudes before reading one of three statements (control, populist, and populist nostalgic) on safety in public places. After reading, participants were asked for their agreement with the statement, about the topic of the statement, and whether they thought the statement was objective or sensational. After providing demographic variables, participants were debriefed.

\subsubsection{Measures}

If not stated differently, all scales were measured on a 5 -point scale $(1=$ do not agree at all; $5=$ strongly agree). We measured populist attitudes using 12 items, 
part of which were taken from Akkerman, Mudde, and Zaslove's (2014) populist attitude scale. The scale contains different facets subsumed under the umbrella of populism (populism, [anti-]elitism, and [anti-]diversity), we decided to use an overall index of all three dimensions $(M=3.07, S D=0.65, \alpha=0.84)$. For the full translated scale, see Table S1 in the Supplementary File (https://osf.io/fm5rg). Participants did not differ regarding overall populist attitudes between conditions, $F(2,170)=1.28$, n.s.

We assessed the objectivity of the shown statement with two items ("The statement was objective" and "The statement was sensational"). These two items correlated adequately with each other $(M=2.21, S D=1.01$, Spearman-Brown $=0.61$ ). We further measured agreement with the statement with a single item ("Please indicate your agreement to this statement"; $M=2.38$, $S D=1.15)$.

\subsubsection{Stimulus Selection}

Drawing from Study 1, we selected one statement from AfD's campaign newspaper claiming that safety in public spaces has decreased dramatically compared to the past. As it is typical populist rhetoric, this original statement also contained colloquial and sensational speech (e.g., "Kriminalitätskloake," literally a "cesspool of criminality"). For the statements and adaptations used in Study 2, see Appendix A in the Supplementary File. Participants in the non-nostalgic populist group read the original populist statement but we cut the part that referred to the past. The nostalgic populist group was shown the same statement, but it comprised passages that emphasized a dramatic change compared to the past. To enhance the nostalgic sentiment, a sentence was added by the authors stating that in the past, children could be carefree when playing outside and one did not have to drive them to the kindergarten. The control group was shown a statement that presented the statement more objectively. For this purpose, we cut sensational language (e.g., "cesspool of criminality"), the reference to change compared to the past, and the nostalgic sentence about carefree children. The manipulation check shows that participants in the neutral statement condition $(M=2.72, S D=0.97)$ perceived the statement as more objective than in the populist nostalgic $(M=2.08$,
$S D=1.03)$ and populist $(M=1.89, S D=0.86)$ conditions, $F(2,170)=11.33, p<0.001$.

\subsection{Results}

Zero-Order correlations of the measured variables for the total sample as well as for all conditions can be found in Table S2 in the Supplementary File (https://osf.io/ $\mathrm{fm} 5 \mathrm{rg}$ ). To assess whether participants differed in their agreement with the statements $(\mathrm{H} 1)$, we conducted an ANOVA with statement condition as independent and agreement as dependent variable. Results show that participants differed between conditions in agreement to the statement, $F(2,170)=12.21, p<0.001, \eta_{p}^{2}=0.13$. In particular, the control statement achieved highest agreement $(M=2.91, S E=0.15)$, the populist statement lowest agreement $(M=1.90, S E=0.14)$, and the nostalgic populist statement fell in between $(M=2.38$, $S E=0.14)$. All means differed significantly from each other (control-nostalgic populist: $\Delta M=0.52, S E=0.20$, $p=0.033$; nostalgic populist - populist: $\Delta M=0.48$, $S E=0.20, p=0.045)$. These findings illustrate that while the pure populist rhetoric scored low on agreement, nostalgic rhetoric was able to partly 'bolster' rejection of populist speech, supporting $\mathrm{H} 1$.

To further investigate the role of trait populist attitudes in these differences (RQ5), we conducted a moderation analysis using the PROCESS macro (Hayes, 2018, Model 1). We compared the agreement of participants in the nostalgic populist condition with the agreement of participants in both other conditions using condition as a multi-categorical predictor and included trait populist attitude as moderator. Means were centred for the construction of products using the respective function in the PROCESS macro. Results displayed in Table 1 show a significant interaction term. People scoring high (compared to those scoring low) on populist attitudes agreed more strongly with the nostalgic compared to both the control and the non-nostalgic populist statements. These findings support $\mathrm{H} 2$, which assumed that populist attitudes moderate the effect of nostalgic rhetoric on acceptance.

\subsection{Discussion}

Study 2 used one particular statement about public safety from the election campaign and compared how

Table 1. Linear moderation model predicting agreement with the statement.

\begin{tabular}{|c|c|c|c|c|}
\hline & $b[\mathrm{Cl}]$ & $S E B$ & $t$ & $p$ \\
\hline Constant & $2.33[2.09,2.57]$ & 0.12 & 19.00 & $<0.001$ \\
\hline Condition 1 (nostalgic populist versus control) & $0.55[0.19,0.90]$ & 0.18 & 3.05 & 0.003 \\
\hline Condition 2 (nostalgic populist versus non-nostalgic populist) & $-0.39[-0.74,-0.05]$ & 0.17 & -2.26 & 0.025 \\
\hline Populist attitudes & $1.29[0.91,1.66]$ & 0.19 & 6.84 & $<0.001$ \\
\hline Condition $1 \times$ Populist attitudes & $-0.91[-1.47,-0.36]$ & 0.28 & -3.24 & 0.002 \\
\hline Condition $2 \times$ Populist attitudes & $-0.95[-1.47,-0.43]$ & 0.26 & -3.60 & $<0.001$ \\
\hline
\end{tabular}

Notes: Condition was entered as a multi-categorical predictor with the nostalgic populist condition serving as the reference group. $R^{2}=0.33$. 
statements with either nostalgic or non-nostalgic populist rhetoric performed in terms of agreement. The results show two important findings: First, the non-nostalgic populist rhetoric performed weaker in acceptance than the nostalgic populist rhetoric. Second, populist attitudes were a significant moderator such that people with strong populist attitudes (people sovereignty, anti-elitism) rated the nostalgic populist statement as more acceptable than those with lower populist attitudes compared to both other conditions.

These findings illustrate that nostalgia can function as a rhetorical tool to 'sugarcoat' populist messages. While the political message and the tone of both populist statements were similar, people agreed more strongly with the nostalgic statement which contained aspects such as change, and being carefree back in childhood. Moreover, nostalgia might particularly impact those who share populist (anti-elitism, anti-diversity) attitudes anyway. Thus, nostalgia in populist rhetoric might work particularly well on individuals who are already prone to such political messages and thus works by maintaining followers rather than addressing new voters. It has to be kept in mind though that we only manipulated and tested one particular (short) message. Also, there was no nostalgic version of the control statement to attest the main effect of nostalgic (but non-populist) rhetoric. Our findings should therefore be taken as a complementary proof of concept within a case study that may induce further research. Nonetheless, these findings are noteworthy because the major part of the sample was higher educated and did disagree with the non-nostalgic populist statement. Our study further aligns with previous findings on the impact of nostalgia in the context of right-wing populist rhetoric. As shown by Lammers and Baldwin (2020), populist nostalgic rhetoric that focused on a challenge that was easier in the past increased people's agreement with the statement. While Lammers and Baldwin showed this in the case of political correctness in generic statements, we replicated their findings for an actual statement of AfD Thuringia's campaign in Germany on the topic of people's personal safety.

\section{Conclusion}

The rise of populism has revealed the vulnerability of conventions in modern democracies which have been taken for granted. In recent campaigns, right-wing populists employed complex affective strategies to undermine trust in democracy and non-native citizens. Nostalgia has become a prominent feature in most of them. Our studies examined the 'dark' potential of nostalgia and showed that it is used to mobilize supporters not only against the status quo and out-groups but also for a vision grounded in their longing for recognition, safety, stability, and the 'heartland.'

Study 1 examined AfD Thuringia's online election campaign and discovered that the precondition of presenting a nostalgically informed vision for the future is its contrast to a present in crisis. However, this crisis is not just depicted in its effects on the 'common man' but is additionally tied to the claimed wrongdoings of elites and out-groups. In this specific case, AfD also channelled frustration about the fallout following reunification, economic inequalities, and the perceived lack of recognition for East Germans. The results also show that nostalgia does not have to be anchored in a historical period. Instead, it is enough to offer a moment in time that had the potential for a better future to be realized but which has, as yet, not materialized. One could say that it is a nostalgia for the bygone potential that has led to the idea of the 'heartland.' Finally, results also stress that right-wing populism does not promote a bright 'return to the future' for everybody as the xenophobic dimension excludes those who are not considered members of the 'heartland.'

Study 2 built on these findings by focusing on a statement about safety in public spaces from the campaign material. The results indicate that the persuasive effects of nostalgia exist and that they partly depend on the populist attitudes of individuals. The populist statement with nostalgia led to more agreement than the one without nostalgic rhetoric. Moderation analyses showed that this applies especially to those participants with stronger populist attitudes. This suggests that nostalgia might perform especially well as a communicative tool to mobilize those who are already receptive to populist messages. However, this interpretation is preliminary and has to be replicated in other studies.

Concerning the limitations of our framework, it is important to emphasize that we followed an interdisciplinary attempt to nostalgia by integrating political communication and psychological perspectives. While both studies inform each other, the integration respected the theoretical and methodological conditions of each field and the subsequent shortcomings. For Study 1 , the interpretative, qualitative approach is limited to the online material and therefore is neither a holistic analysis of the whole campaign nor its mediated dissemination during the Thuringia election. For Study 2, we only used one particular statement that is hardly applicable to the overall rhetoric of AfD regarding external validity. We hope that with our work we offer researchers on this intersection a meaningful contribution that will help broaden the scope of research.

We would like to conclude by highlighting that the material of the AfD online campaign was distributed and controlled by the party. This direct communication between the party and its supporters potentially removes the layer of controversy we usually find in mass media coverage of populist parties and their messages. It is important to further investigate if there is controversy about nostalgically informed visions in social media or journalistic media that counter false promises and manipulated emotions. Both studies show that creating a sense of crisis usually precedes nostalgic narratives. Therefore, disarming populism might mean first and 
foremost countering the exaggerated crisis rhetoric and becoming aware of widespread sentiments. The potential of nostalgia might even turn 'lucid' when it is used to understand what people are longing for in times of crisis. This knowledge can contribute to solutions facilitating cohesion in liberal democracies instead of in- and out-group thinking such as that promoted by right-wing populism.

\section{Acknowledgments}

We would like to thank the students from our course at the Department of Media and Communication, LMU Munich, for the insightful discussions and their support during the project. The collaborative work not only improved the course but also resulted in the solid empirical research we proudly present in this article. Additionally, we would like to thank the editors and reviewers for their valuable remarks that helped us to improve the paper.

\section{Conflict of Interests}

The authors declare no conflict of interests.

\section{Supplementary Material}

Supplementary material for this article is available online in the format provided by the author (unedited). Further material (data, syntax, coded material) can be assessed on the open science framework (https://doi.org/ 10.17605/OSF.IO/ZNPGT)

\section{References}

AfD Thuringia. (2019a, October 16). Holen wir uns unser Land zurück! \#AfD [Let us take our country back! \#AfD] [Video file]. Retrieved from https://www. facebook.com/AfD.Thueringen/videos/11779115224 03801

AfD Thuringia. (2019b). Meine Heimat, mein Thüringen [My home, my Thuringia]. [Election manifesto]. Berlin: AfD Thuringia. Retrieved from https://cdn.afd. tools/wp-content/uploads/sites/178/2019/09/ Wahlprogramm_AfD-Thu\%CC\%88ringen_2019_ Online-Fassung-final_gesichert.pdf

AfD Thuringia. (2019c). Kein Bock auf Block-Parteien [Fed up with bloc parties] [Pamphlet]. Berlin: AfD Thuringia. Retrieved from https://www.afdthueringen.de/wp-content/uploads/sites/178/2019/ 09/Wahlkampf-Comic_Flugblatt.pdf

AfD Thuringia. (2019d, October 24). Die \#linke im Panikmodus: Die Thüringer Linke befindet sich im Panikmodus, zeigen doch die Umfragen der letzten Zeit eine klare Abwahl der derzeitigen Landesregierung voraus [The \#Left in panic mode: The Thuringian Left is in panic mode because recent surveys obviously show that the current state gov- ernment will not be re-elected] [Facebook status update]. Retrieved from https://www.facebook. com/AfD.Thueringen/posts/1435629173256244

AfD Thuringia. (2019e). Our election posters. AfD Thuringia. Retrieved from https://www.afdthueringen.de/landtagswahl-2019/ wahlkampfmittel-zur-landtagswahl

AfD Thuringia. (2019f, October 21). Unser Radiospot zur Landtagswahl [Our radio commercial for the federal election] [Video file]. Retrieved from https:// www.afd-thueringen.de/thuringen-2/2019/10/ unser-radiospot-zur-landtagswahl

AfD Thuringia. (2019g, October 21). Familie ist Zukunft [Family is the future] [Pamphlet]. Berlin: AfD Thuringia. Retrieved from https://afd-thl.de/ download/16761

Akkerman, A., Mudde, C., \& Zaslove, A. (2014). How populist are the people? Measuring populist attitudes in voters. Comparative Political Studies, 47(9), 1324-1353. https://doi.org/10.1177/00104140135 12600

Betz, H., \& Johnson, C. (2004). Against the current: Stemming the tide-The nostalgic ideology of the contemporary radical populist right. Journal of Political Ideologies, 9(3), 311-327. https://doi.org/10.1080/ 1356931042000263546

Bonnett, A. (2010). Left in the past: Radicalism and the politics of nostalgia. New York, NY: Continuum.

Bourke, R. (2018). What is conservatism? History, ideology and party. European Journal of Political Theory, 17(4), 449-475. https://doi.org/10.1177/ 1474885118782384

Boym, S. (2001). The future of nostalgia. New York, NY: Basic Books.

Boym, S. (2007). Nostalgia and its discontents. The Hedgehog Review: The uses of the past, 9(2), 7-18.

Browning, C. S. (2019). Brexit populism and fantasies of fulfilment. Cambridge Review of International Affairs, 32(3), 222-244. https://doi.org/10.1080/09557571. 2019.1567461

Campanella, E., \& Dassù, M. (2019). Anglo nostalgia: The politics of emotion in a fractured West. Oxford and New York, NY: Oxford University Press.

Daneels, R., Bowman, N. D., Possler, D., \& Mekler, E. D. (2021). The 'eudaimonic experience': A scoping review of the concept in digital games research. Media and Communication, 9(2), 178-190.

Davis, F. (1977). Nostalgia, identity and the current nostalgia wave. The Journal of Popular Culture, 11(2), 414-424. https://doi.org/10.1111/j.00223840.1977.00414.x

Dresing, T., \& Pehl, T. (2020). f4analyse (3.0) [Computer software]. Marburg: dr. dresing \& pehl $\mathrm{GmbH}$.

Hameleers, M. (2018). A typology of populism: Toward a revised theoretical framework on the sender side and receiver side of communication. International Journal of Communication, 12, 2171-2190.

Hayes, A. F. (2018). Introduction to mediation, modera- 
tion, and conditional process analysis: A regressionbased approach (2nd ed.). New York, NY: Guilford Press.

Höcke, B. [Björn]. (2019, October 21). Lieber Eichsfelder, lieben Sie eigentlich $\mathrm{hr}$ Land? [Dear Eichsfelder, do you actually love your country?] [Facebook status update]. Retrieved from https://www.facebook. com/Bjoern.Hoecke.AfD/posts/2456309801276958

Hsieh, H.-F., \& Shannon, S. E. (2005). Three approaches to qualitative content analysis. Qualitative Health Research, 15(9), 1277-1288. https://doi.org/ $10.1177 / 1049732305276687$

Inglehart, R. F., \& Norris, P. (2016). Trump, Brexit, and the rise of populism: Economic have-nots and cultural backlash (HKS Faculty Research Working Paper Series No. RWP16-026). Cambridge, MA: Harvard Kennedy School. Retrieved from https://www.hks. harvard.edu/publications/trump-brexit-and-risepopulism-economic-have-nots-and-cultural-backlash

Karakaya, Y. (2020). The conquest of hearts: The central role of Ottoman nostalgia within contemporary Turkish populism. American Journal of Cultural Sociology, 8(2), 125-157. https://doi.org/10.1057/s41290-0180065-y

Kay, J. B., Mahoney, C., \& Shaw, C. (Eds.). (2017). The past in visual culture: Essays on memory, nostalgia and the media. Jefferson, NC: McFarland.

Kenny, M. (2017). Back to the populist future? Understanding nostalgia in contemporary ideological discourse. Journal of Political Ideologies, 22(3), 256-273. https://doi.org/10.1080/13569317.2017.1346773

Krämer, B. (2017). Populist online practices: The function of the Internet in right-wing populism. Information, Communication \& Society, 20(9), 1293-1309. https://doi.org/10.1080/1369118X.2017.1328520

Lammers, J., \& Baldwin, M. (2020). Make America gracious again: Collective nostalgia can increase and decrease support for right-wing populist rhetoric. European Journal of Social Psychology, 50(5), 943-954. https://doi.org/10.1002/ejsp.2673

Mayring, P. (2014). Qualitative content analysis: Theoretical foundation, basic procedures and software solution. SSOAR. http://nbn-resolving.de/urn:nbn: de:0168-ssoar-395173

Menke, M. (2017). Seeking comfort in past media: Modeling media nostalgia as a way of coping with media change. International Journal of Communication, 11, 626-646.

Moffitt, B., \& Tormey, S. (2014). Rethinking populism: Politics, mediatisation and political style. Political Studies, 62(2), 381-397. https://doi.org/10.1111/14679248.12032

Mudde, C. (2004). The populist zeitgeist. Government and Opposition, 39(4), 541-563.

Pickering, M., \& Keightley, E. (2006). The modalities of nostalgia. Current Sociology, 54(6), 919-941. https:// doi.org/10.1177/0011392106068458

Saunders, A., \& Pinfold, D. (Eds.). (2013). Remem- bering and rethinking the GDR. London: Palgrave Macmillan UK. Retrieved from https://doi.org/ 10.1057/9781137292094

Sedikides, C., Wildschut, T., Cheung, W.-Y., Routledge, C., Hepper, E. G., Arndt, J., . . . Vingerhoets, A. J. J. M. (2016). Nostalgia fosters self-continuity: Uncovering the mechanism (social connectedness) and consequence (eudaimonic well-being). Emotion, 16(4), 524-539. https://doi.org/10.1037/emo0000136

Smeekes, A. (2015). National nostalgia: A group-based emotion that benefits the in-group but hampers intergroup relations. International Journal of Intercultural Relations, 49, 54-67. https://doi.org/10.1016/ j.ijintrel.2015.07.001

Smeekes, A., Jetten, J., Verkuyten, M., Wohl, M. J. A., Jasinskaja-Lahti, I., Ariyanto, A., . . . van der Bles, A. M. (2018). Regaining in-group continuity in times of anxiety about the group's future: A study on the role of collective nostalgia across 27 countries. Social Psychology, 49(6), 311-329. https://doi.org/ 10.1027/1864-9335/a000350

Smeekes, A., Wildschut, T., \& Sedikides, C. (in press). Longing for the "good old days" of our country: National nostalgia as a new master-frame of populist radical-right parties. Journal of Theoretical Social Psychology.

Stanley, B. (2008). The thin ideology of populism. Journal of Political Ideologies, 13(1), 95-110. https://doi.org/ 10.1080/13569310701822289

Steele, B. J., \& Homolar, A. (2019). Ontological insecurities and the politics of contemporary populism. Cambridge Review of International Affairs, 32(3), 214-221. https://doi.org/10.1080/09557571. 2019.1596612

Taggart, P. (2004). Populism and representative politics in contemporary Europe. Journal of Political Ideologies, 9(3), 269-288. https://doi.org/10.1080/ 1356931042000263528

Tannock, S. (1995). Nostalgia critique. Cultural Studies, 9(3), 453-464. https://doi.org/10.1080/095023 89500490511

Van Tilburg, W. A. P., Igou, E. R., \& Sedikides, C. (2013). In search of meaningfulness: Nostalgia as an antidote to boredom. Emotion, 13(3), 450-461. https://doi.org/ $10.1037 / \mathrm{a} 0030442$

Velikonja, M. (2009). Lost in transition: Nostalgia for socialism in post-socialist countries. East European Politics \& Societies, 23(4), 535-551. https://doi.org/ $10.1177 / 0888325409345140$

Weisskircher, M. (2020). The strength of far-right AfD in Eastern Germany: The east-west divide and the multiple causes behind 'populism.' The Political Quarterly, 91(3), 614-622. https://doi.org/10.1111/1467923X.12859

Wildschut, T., Sedikides, C., Routledge, C., \& Arndt, J. (2006). Nostalgia: Content, triggers, functions. Journal of Personality and Social Psychology, 91(5), 975-993. 
Wildschut, T., Sedikides, C., Routledge, C., Arndt, J., \& Cordaro, F. (2010). Nostalgia as a repository of social connectedness: The role of attachment-related avoidance. Journal of Personality and Social Psychology, 98(4), 573-586. https://doi.org/10.1037/ a0017597

Wohl, M. J. A., Stefaniak, A., \& Smeekes, A. (2020). Days of future past: Concerns for the group's future prompt longing for its past (and ways to reclaim it). Current Directions in Psychological Science, 29(5), 481-486. https://doi.org/10.1177/ 0963721420924766

Wulf, T., Bonus, J. A., \& Rieger, D. (2019). The inspired time traveler: Examining the implications of nostalgic entertainment experiences for two-factor models of entertainment. Media Psychology, 22(5), 795-817. https://doi.org/10.1080/15213269.2018.1532299

\section{About the Authors}

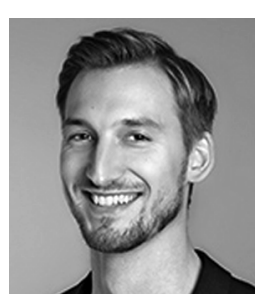

Manuel Menke (PhD) is an Assistant Professor at the Department of Communication, University of Copenhagen, Denmark. His research interests comprise (theories of) social and media change, media and nostalgia, mediated memories, digital public spheres, and journalism research.

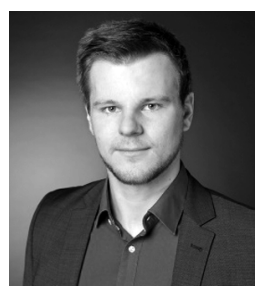

Tim Wulf $(\mathrm{PhD})$ is a Post-Doctoral Researcher at the Department of Media and Communication at LMU Munich in Germany. His research interests include media-induced nostalgia, the uses and effects of video games, and persuasion through narrative media. For more information, see https:// www.tim-wulf.de 